\title{
Profil Kemampuan Pemecahan Masalah Matematika Pada Materi Segitiga Berdasarkan Teori Van Hielle
}

\author{
Viyang Firnanda ${ }^{*}$ dan Fika Widya Pratama ${ }^{2}$ \\ Pendidikan Matematika, Universitas Kristen Satya Wacana \\ Jalan Diponegoro No. 52-60 Salatiga, Jawa Tengah, Indonesia \\ ${ }^{1 * 202015026 @ s t u d e n t . u k s w . e d u ; ~}{ }^{2}$ fika.pratama@uksw.edu
}

Artikel diterima: 20-05-2020, direvisi: 26-09-2020, diterbitkan: 30-09-2020

\begin{abstract}
Abstrak
Masalah dalam penelitian ini yaitu kemampuan pemecahan masalah siswa yang rendah pada materi segitiga. Penelitian ini bertujuan untuk mendeskripsikan profil kemampuan pemecahan masalah matematika pada materi segitiga berdasarkan Teori Van Hiele. Jenis penelitian ini adalah deskriptif kualitatif. Instrumen utama adalah peneliti itu sendiri, dibantu instrumen pendukung yang terdiri dari 3 soal tes berupa soal uraian sesuai dengan indikator Van Hiele dan pedoman wawancara yang semi terstruktur.Teknik analisis data menggunakan 4 tahapan yaitu pengumpulan data, reduksi data, penyajian data, dan penarikan kesimpulan. Waktu penelitian dilakukan pada tanggal 13 November sampai 14 Desember 2019 semester ganjil tahun ajaran 2019/2020. Subjek penelitian sebanyak 3 siswa kelas VIII SMP Negeri 2 Salatiga dengan hasil belajar matematika tinggi, sedang, dan rendah. Data yang terkumpul dianalisis menggunakan tahap berpikir Van Hiele. Hasil penelitian ini menemukan bahwa siswa dengan hasil belajar matematika tinggi mencapai tahap 0 (visualisasi). Siswa dengan hasil belajar matematika sedang mampu mencapai tahap 1 (analisis). Siswa dengan hasil belajar matematika rendah mencapai tahap 0 (visualisasi). Kesimpulan penelitian ini adalah tahap berpikir Van Hiele pada setiap siswa berbeda-beda berdasarkan kemampaun pemecahan yang dimiliki setiap siswa. .

Kata kunci: Hasil Belajar, Pemecahan masalah matematika, Segitiga, Teori Van Hiele
\end{abstract}

\section{Profile of Mathematical Troubleshooting Abilities In The Triangle Material Based On Van Hiele Theory}

\begin{abstract}
The problem in this study is students' problem-solving ability is low on triangle material. This study aims to describe the profile of mathematical problem-solving abilities on a triangular material based on the Van Hiele's Theory. This type of research is descriptive qualitative. The main instrument was the researcher himself, assisted by supporting instruments consisting of 3 test questions in the form of a matter of description following Van Hiele indicators and semi-structured interview guidelines. The data analysis technique uses 4 stages, data collection, data reduction, data presentation, and drawing conclusions. The time of the research studies conducted on November 13 until December 14 2019 on the odd semester of the 2019/2020 year. Research subjects were 3 students of class VIII of SMP Negeri 2 Salatiga with high, medium, and low mathematics learning outcomes. The collected data were analyzed using Van Hiele's thinking stage. The results of this study found that students with high mathematics learning outcomes reached stage 0 (visualization). Students with medium mathematics learning outcomes were able to reach stage 1 (analysis). Students with low mathematics learning outcomes reached stage 0 (visualization). The conclusion of this study is that Van Hiele's thinking stage for each student is different based on the solving ability of each student Keywords: Learning Outcomes, Mathematical Problem Solving, Triangle, Van Hiele Theory
\end{abstract}




\section{Pendahuluan}

Proses pembelajaran matematika yang kurang melibatkan masalah kontekstual dan HOTS menyebabkan rendahnya kemampuan pemecahan masalah siswa (Wardani, 2012; Latifah \& Madio, 2014; Afriansyah, 2016; Kurniawati \& Rizkianto, 2018; Asih \& Ramdhani, 2019). Faelasofi, dkk (2015) menemukan bahwa kebanyakan siswa saat memecahkan masalah kurang memperhatikan urutan jawaban, serta siswa kesulitan ketika diminta untuk mendeskripsikan atau membuat pertanyaan yang berkaitan dengan ilustrasi atau gambar yang disajikan oleh guru.

Penelitian yang dilakukan Yustianingsih dkk (2017) menunjukkan bahwa kemampuan pemecahan masalah yang dimiliki siswa masih rendah karena belum terbiasa dengan soalsoal kontekstual sehingga kemampaun pemecahan masalah mereka belum terlatih. Kemampuan pemecahan masalah siswa rendah juga disebabkan karena kurangnya pemahaman siswa dalam menyelesaikan masalah kontekstual sehingga siswa belum terbiasa dengan pembelajaran HOTS.

Masih rendahnya kemampuan pemecahan masalah harus diperhatikan dengan baik karena kemampuan pemecahan masalah memiliki peran yang penting (Wahyuni, 2016; Albab, Saputro, \& Nursyahidah, 2017; Muhammad, Septian, \& Sofa, 2018; Rinaldi \& Afriansyah, 2019). Menurut Sumartini (2016), setiap siswa wajib memiliki kemampuan pemecahan masalah karena itu sangat penting. Croft, dkk. (2018) mengemukakan bahwa pemecahan masalah dapat berperan sebagai sarana untuk mengembangkan pemikiran matematika sebagai alat untuk hidup sehari-hari.

Pemecahan masalah merupakan salah satu dari tujuan pembelajaran geometri, yaitu supaya siswa mendapatkan rasa percaya diri pada kemampuan matematikanya, terampil dalam pemecahan masalah, dapat berkomunikasi secara matematik, serta mampu bernalar secara matematik ( $\mathrm{Nadz}$ \& Haq, 2013; Siregar, 2016; Ekayanti, 2017; Shadiq, 2009: 148; Asmara \& Afriansyah, 2018; Suryani, Jufri, \& Putri, 2020; Rismen, Mardiyah, \& Puspita, 2020). Penelitian Sholihah \& Afriansyah (2017) menemukan bahwa kebanyakan siswa masih kesulitan untuk menggunakan rumus dalam memecahkan masalah geometri, tak jarang juga siswa masih belum mengerti maksud soal yang diberikan.

Hasil penelitian Muhassanah, dkk (2014) menemukan bahwa ketika memecahkan masalah siswa tidak dapat merencanakan strategi penyelesaian masalah dengan baik, sehingga saat mengidentifikasi bangun geometri siswa tidak bisa menentukan cara yang harus digunakan untuk memecahkan masalah tersebut.

Sub pokok materi geometri yang melibatkan pemecahan masalah adalah bangun datar (Rahmiati, Musdi, \& Fauzi, 2017; Tristiani \& Afriansyah, 2017; Lisnani \& Asmaruddin, 2018). Materi bangun datar merupakan materi yang bisa digunakan ketika pembelajaran matematika untuk mengembangkan suatu kemampuan pemecahan masalah (Mustakim, 2017; Sopian \& Afriansyah, 2017; Lisnani, 2019; Muslim \& Prabawati, 2020). Menurut Permendikbud No 21 tahun 2016 tentang Kompetensi Dasar pada materi pokok segitiga dan segiempat jenjang Sekolah Menengah Pertama, siswa diharapkan mampu memahami sifat-sifat atau ciri-ciri yang dimiliki bangun datar, dan menghubungkannnya. Penelitian ini memilih segitiga sebagai pokok bahasan karena 
terdapat beberapa kesulitan yang dialami siswa.

Melalui uraian masalah di atas, untuk mengetahui kemampuan pemecahan masalah pada materi geometri bangun datar segitiga, kita dapat menggunakan Teori Van Hiele. Analisis menggunakan Teori Van Hiele dengan alasan sebagai berikut: (1) Teori Van Hiele memudahkan dan mengarahkan siswa saat belajar matematika supaya memahami konsep matematika sesuai dengan tingkat berpikir siswa, (2) Teori Van Hiele memaksimalkan siswa supaya memiliki pengetahuan tentang konsep matematika sesuai dengan pembelajaran konstruktivisme. Teori Van Hiele yang digunakan dalam penelitian ini merupakan teori yang berkaitan dengan tingkat berpikir seseorang, yaitu dari tingkat berpikir sederhana sampai tingkat berpikir kompleks (dalam Beishuizen, Gravemeijer, dan Lieshout, 1997: 34; Sholihah \& Afriansyah, 2017). Menurut Piere Van Hiele dan Dina Van Hiele-Geldof dalam belajar geometri seseorang akan melalui lima tahapan hierarkis (Van de Walle, 2002) yaitu, tahap 0 pengenalan (visualisasi), tahap 1 analisis (analysis), tahap 2 deduksi informal, tahap 3 deduksi, tahap 4 ketepatan (rigor).

Beberapa hasil penelitian tentang teori Van Hiele yang dilakukan sebelumnya menunjukkan kurangnya hasil belajar tentang geometri. Pinar (2014) menyatakan bahwa tingkat berpikir geometri siswa SMP berdasarkan teori Van Hiele masih rendah. Budiarti (2016) tahapan tertinggi yang dicapai siswa dalam pemecahan masalah berada pada tahap 0 (visualisasi). Penelitian Wahyudi (2016) menemukan bahwa rata-rata siswa mencapai tahap visualisasi hanya sedikit yang mencapai tahap analisis.
Berdasarkan uraian masalah di atas, maka rumusan masalah dalam penelitian ini adalah untuk mengetahui bagaimana kemampuan pemecahan siswa dengan hasil belajar matematika tinggi, sedang, dan rendah menyelesaikan soal materi segitiga berdasarkan Teori Van Hiele. Harapan dalam penelitian ini adalah siswa dapat memiliki kememapuan pemecahan masalah yang baik pada materi segitiga

\section{Metode}

Jenis penelitian ini adalah penelitian kualitatif yang bersifat deskriptif (Kaelan 2005: 58; Afriansyah, 2015). Subjek penelitian ini merupakan 3 siswa kelas VIII SMP N 2 Salatiga tahun ajaran 2019/2020. Pengambilan subjek menggunakan teknik purposive sampling. Subjek dipilih berdasarkan pertimbangan: (1) Sudah pernah belajar segitiga, (2) Terdiri dari subjek dengan hasil belajar matematika tinggi, sedang dan rendah, (3) bersedia terlibat di dalam penelitian ini. Subjek dipilih berdasarkan penilaian akhir semester yang kemudian dikelompokkan menjadi siswa 3 dengan hasil belajar matematika tinggi, sedang, dan rendah. Berdasarkan pengelompokkan tersebut kemudian dipilih masing-masing satu dari ketiga kemampuan matematika tersebut. Sehingga diperoleh NN (siswa dengan hasil belajar matematika tinggi), $A D$ (siswa dengan hasil belajar matematika sedang), MA (siswa dengan matematika rendah).

Instrumen yang digunakan terdiri dari instrumen utama dan instrumen bantu, instrumen utama adalah peneliti itu sendiri sedangkan instrumen bantu berupa soal tes, pedoman wawancara, dan dokumentasi. 
Adapun salah satu contoh instrumen yaitu sebagai berikut.

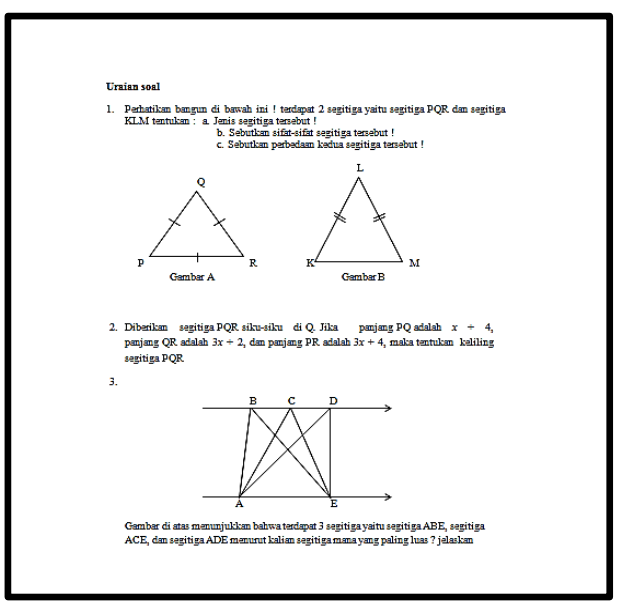

Gambar 1. Soal tes kemampuan pemecahan masalah segitiga.

Soal tes terdiri dari 3 butir soal uraian pemecahan masalah pada materi segitiga yang memenuhi indikator Van Hiele serta telah divalidasi oleh satu dosen matematika dan satu guru matematika SMP Negeri 2 Salatiga. Soal 1 tentang indentifikasi segitiga berdasarkan gambar, soal 2 tentang keliling segitiga yaitu menghitung keliling segitiga siku-siku yang telah diketahui sisi-sisinya dalam bentuk aljabar, soal 3 tentang luas segitiga yaitu mencari segitiga yang paling luas dari 3 segitiga pada soal.

Pedoman wawancara digunakan untuk memverifikasi data dari hasil tes, kemudian hasil wawancara ditulis dalam bentuk transkrip. Dokumentasi penelitian berupa rekaman suara, foto proses pengerjaan subjek, serta hasil belajar matematika siswa pada Penilaian Akhir Semester Ganjil Tahun Ajaran 2019/2020. Analisis data menggunakan 4 tahapan (Sugiono, 2014), yaitu pengumpulan data (mengumpulkan semua data dari lapangan), reduksi data (pemilihan data pokok yang akan dianalisis), penyajian data (proses penyusunan informasi secara sistematis untuk memperoleh kesimpulan), dan kesimpulan (hasil dari analisis data yang berasal dari tes dan wawancara).

\section{Hasil dan Pembahasan}

\section{A. Hasil}

Hasil penelitian profil kemampuan pemecahan masalah segitiga berdasarkan teori Van Hiele adalah sebagai berikut.

1. Profil Kemampuan Pemecahan Masalah Subjek dengan Hasil Belajar Matematika Tinggi (NN)

Hasil analisis data penelitian menunjukan bahwa siswa dengan hasil belajar matematika tinggi pada soal no. 1 tidak mencapai tahap 0 (visualisasi). Hal ini dikarenakan subjek NN tidak dapat menentukan jenis segitiga pada soal dengan benar, dapat dilihat pada gambar 2.

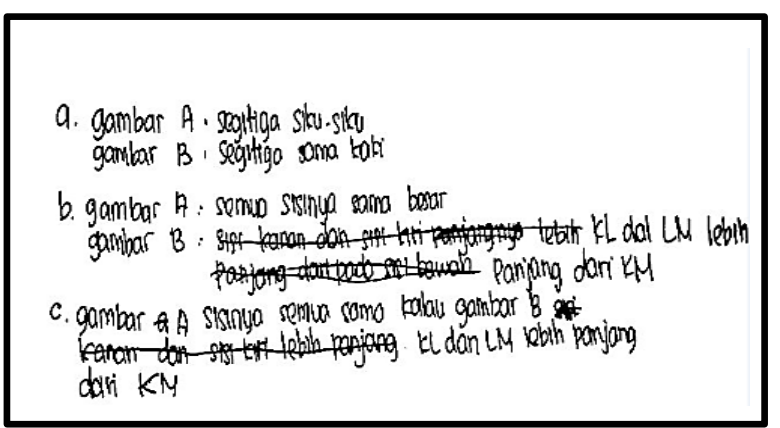

Gambar 2. Jawaban subjek NN soal no. 1.

Jawaban tertulis subjek NN terlihat bahwa segitiga sama sisi adalah segitiga siku-siku dengan alasan bahwa segitiga sama sisi semua sudutnya adalah sudut siku-siku. Hal ini sejalan dengan hasil wawancara subjek NN mengatakan bahwa semua sudut segitiga sama sisi adalah segitiga siku-siku dan menunjukkan bahwa sudut $P$ pada segitiga sama sisi adalah segitiga siku-siku. Hal tersebut dikarenakan subjek NN kurang memahami konsep segitiga, hal ini terlihat dari jawaban NN yang masih bingung membedakan segitiga sama sisi dengan 
segitiga siku-siku. Dapat dibuktikan dari cuplikan wawancara 1 sebagai berikut.

P : Berdasarkan jawaban anda tertulis bahwa gambar A adalah segitiga siku-siku, jelaskan kenapa segitiga gambar A adalah segitiga siku-siku?

NN : Karena semua sikunya itu sama

$P$ : Semua apa?

NN : Sikunya

$\mathrm{P}$ : Mana yang menunjukan bahwa itu sudut siku-siku?

NN : Besarnya kelihatan sama

$P$ : Sudut itu yang mana sih?

NN : Emm, sudutnya ini (sambil menunjuk sudut P pada segitiga sama sisi)

P : Menurut anda sudut $P$ adalah sudut siku-siku? NN : lya

Berdasarkan jawaban tertulis dan wawancara maka subjek NN pada soal no. 1 belum mencapai tahap 0 (visualisasi).

Hasil analisis data penelitian menunjukan bahwa siswa dengan hasil belajar matematika tinggi pada soal no. 2 tidak mencapai tahap 0 (visualisasi), subjek NN tidak dapat menggambar segitiga siku-siku dengan benar, tidak dapat mencari keliling segitiga siku-siku, tidak menggunakan rumus Pythagoras, serta salah konsep penjumlahan aljabar, dapat dilihat pada gambar 3 .

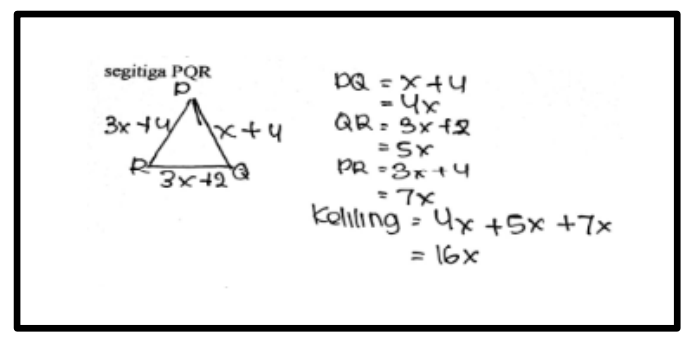

Gambar 3. Jawaban subjek NN soal no. 2.

Jawaban tertulis terlihat bahwa subjek NN tidak dapat menggambar segitiga siku-siku dengan benar, dari jawaban subjek NN terlihat bahwa segitiga yang di gambar adalah segitiga sama sisi sedangkan dalam soal diminta untuk menggambar segitiga siku-siku. Hal tersebut sejalan dengan jawaban pada soal no. 1 dimana subjek NN menganggap bahwa segitiga sama sisi adalah segitiga siku-siku.
Cara subjek NN dalam menghitung keliling segitiga adalah dengan menjumlahkan panjang sisi yang telah diketahui dalam bentuk aljabar dengan hasil jawaban 16x. Hal tersebut menunjukan bahwa subjek NN salah konsep tentang penjumlahan aljabar, subjek NN tidak mencari panjang salah satu sisi segitiga sikusiku dengan rumus Phytagoras dan mengubah bilangan aljabar ke bilangan asli. Berikut ini cuplikan wawancara subjek NN dalam mencari keliling segitiga siku-siku. Perhatikan cuplikan wawancara 2 berikut.

P : Ok langsung saja ya, kemarin cara kamu memperoleh jawaban no 2 ini bagaimana?

NN : Ehmm, itu mas kemarin saya menjumlah panjang $\mathrm{PQ}$ itu kan $x+4$ jadinya $4 x$, terus panjang QR kan $3 x+2$ jadinya $5 x$, yang PR $3 x+4$ kan hasilnya $7 x$ kemudian tak jumlah semua mas jadinya kan $16 x$

Berdasarkan hasil analisis jawaban dan cuplikan wawancara, maka subjek NN belum mencapai tahap 0 (visualisasi). Subjek NN belum bisa mengindentifikasi bangun segitiga, belum bisa mencari keliling segitiga siku-siku dengan benar.

Hasil analisis data penelitian menunjukan bahwa siswa dengan hasil belajar matematika tinggi pada soal no. 3 mencapai tahap 0 (visualisasi) subjek NN dapat mengidentifikasi segitiga yang tedapat dalam soal, subjek NN menemukan segitiga yang paling luas yaitu segitiga ADE dengan perbandingan pada segitiga $A B E$ padahal ketiga segitiga pada soal mempunyai luas yang sama. dapat dilihat pada gambar 4.

Menurut saya segitiga yang paling las adalah ADE kanena jika ABE garis BA lebeh meniorok ke dalam jilka ACE menurut saya lebih ked

Gambar 4. Jawaban subjek NN soal 3

Dari jawaban di atas menunjukan bahwa subjek NN menemukan bahwa segitiga ADE 
adalah segitiga yang paling luas dengan alasan garis $B A$ pada segitiga $A B E$ lebih menjorok ke dalam sehingga terlihat memiliki luas yang lebih kecil padahal tiga segitiga pada soal no. 3 berada pada garis sejajar memiliki alas dan tinggi yang sama sehingga semua segitiga memiliki luas yang sama. Kurangnya pengetahuan subjek NN tentang konsep segitiga mengakibatkan kesalahan dalam mencari luas segitiga pada soal.

Jawaban tertulis subjek NN pada soal no. 3 tidak menunjukkan bahwa subjek NN mampu mencapai tahap 0 (visualisasi) akan tetapi ketika dilakukan wawancara subjek NN mampu mengidentifikasi segitiga yang terdapat pada soal no. 3, hal tersebut dapat dilihat pada cuplikan wawancara 3 sebagai berikut.

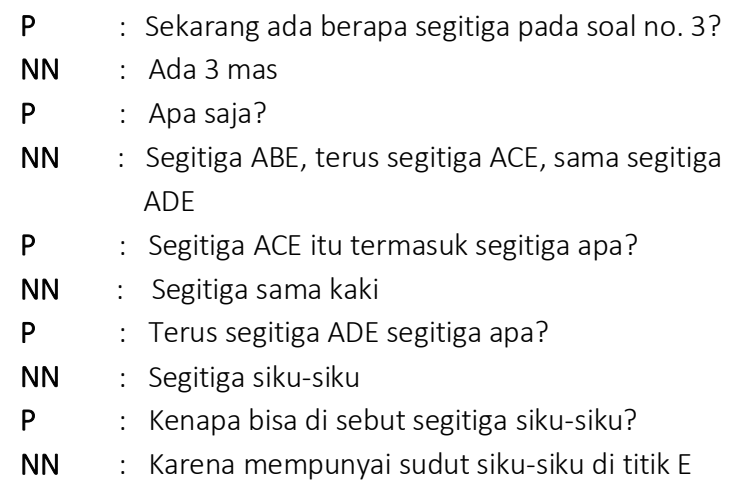

Berdasarkan wawancara tersebut maka subjek NN mencapai tahap 0 (visualisasi), karena subjek NN dapat mengindentifikasi bangun segitiga.

2. Profil Kemampuan Pemecahan Masalah Subjek dengan Hasil Belajar Matematika Sedang (AD)

Hasil analisis data penelitian menunjukan bahwa siswa dengan hasil belajar matematika sedang AD pada soal no. 1 mencapai tahap 1 (analisis). Subjek AD dapat menentukan jenis segitiga, dapat mengidentifikasi segitiga. Dapat dilihat pada gambar 5.

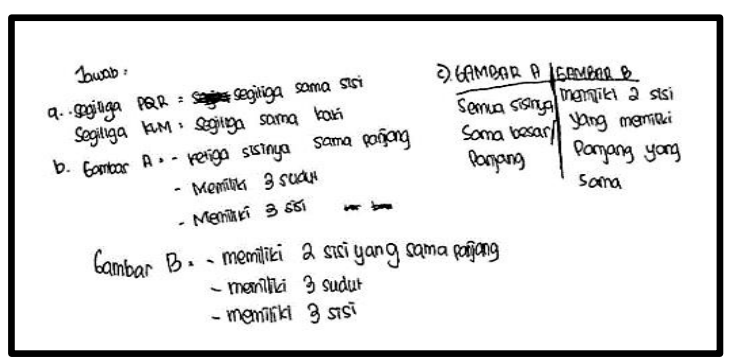

Gambar 5. Jawaban subjek AD Soal 1.

Dari jawaban tertulis terlihat bahwa subjek AD mampu menentukan segitiga berdasarkan jenisnya, menyebutkan ciri-ciri segitiga, serta dapat membedakan segitiga sama sisi dan segitiga sama kaki. Hal ini didukung dengan cuplikan wawancara 4 sebagai berikut.

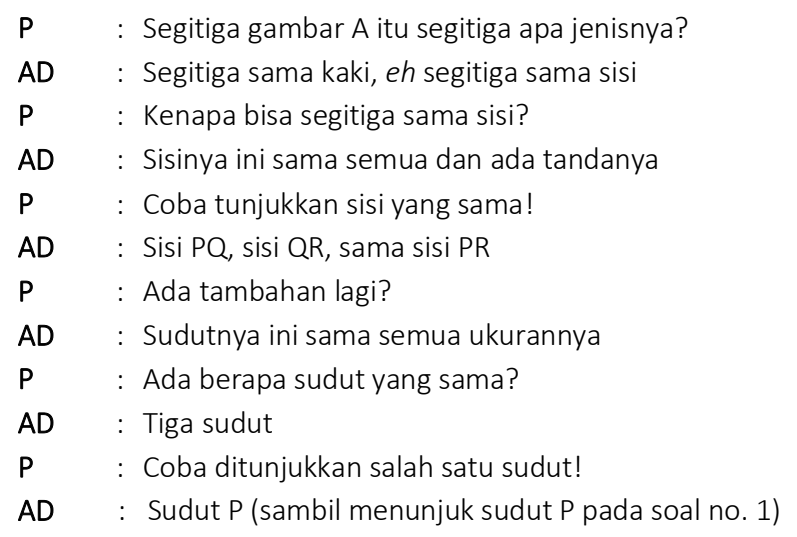

Berdasarkan jawaban tersebut maka subjek AD mencapai tahap 1 (analisis), karena subjek $A D$ dapat mengindentifikasi bangun segitiga.

Hasil analisis data penelitian menunjukan bahwa siswa dengan hasil belajar matematika sedang pada soal no. 2 mencapai tahap 1 (analisis) subjek AD dapat menggambar segitiga siku-siku dengan benar, tetapi masih salah konsep tentang penjumlahan aljabar serta tidak dapat menghitung keliling segitiga siku-siku (lihat gambar 6).

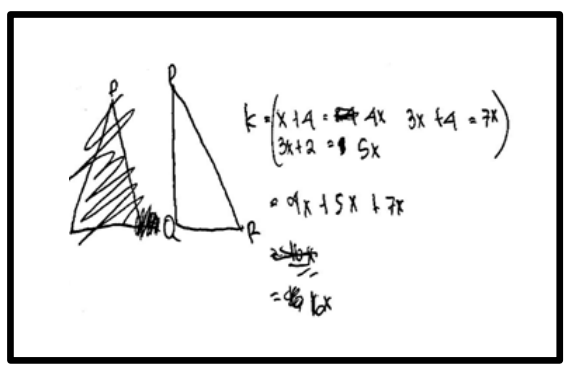

Gambar 6. Jawaban subjek AD soal 2. 
Jawaban tertulis menunjukan bahwa subjek $A D$ dalam mencari keliling segitiga siku-siku masih kurang tepat. Subjek AD tidak mencari panjang sisi segitiga dalam bilangan asli menggunakan rumus Pythagoras, dari jawaban tertulis terlihat subjek $A D$ salah konsep tetang penjumlahan aljabar untuk mencari keliling segitiga. Subjek AD hanya menjumlah panjang semua sisi segitiga sikusiku yang diketahui pada soal. Hal tersebut dibuktikan dengan cuplikan wawancara 5 sebagai berikut.

P : Kenapa hasilnya ini $16 x$ tolong dijelaskan?

$\mathrm{AD} \quad: \quad$ Itu kan $x+4=4 x, 3 x+4=7 x, 3 x+2=5 x$ terus semuanya dijumlah jadinya $16 x$

Subjek AD telah mencapai tahap 1 (analisis), karena mampu menggambar segitiga siku-siku yang diminta pada soal serta dapat menentukan ciri-ciri segitiga siku-siku. Hal tersebut dapat dibuktikan pada cuplikan wawancara 6 sebagai berikut.

$\begin{array}{lll}\text { P } & : \text { Gambar kamu itu segitiga apa? } \\ \text { AD } & : \text { Segitiga siku-siku } \\ \text { P } & : \text { Coba tunjukkan apa sih ciri-ciri segitiga siku- } \\ & & \text { siku ? } \\ \text { AD } & : \text { Sudutnya 90 } \\ \text { P } & : \text { Tunjukkan sudut 90 yang mana? } \\ \text { AD } & : \text { Yang ini dititik } Q\end{array}$

Hasil analisis data penelitian menunjukan bahwa siswa dengan hasil belajar matematika sedang pada soal no. 3 mencapai tahap 1 (analisis), subjek $A D$ menjawab bahwa tidak ada segitiga yang paling luas (lihat gambar 7 ).

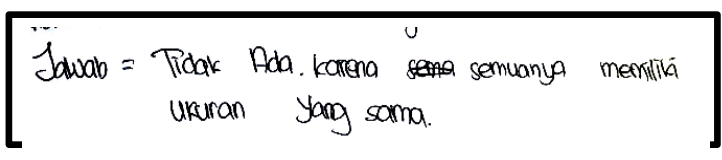

Gambar 7. Jawaban subjek AD soal 3.

Jawaban tertulis terihat bahwa subjek $A D$ menemukan tidak ada segitiga yang paling luas dengan alasan semua segitiga yang terdapat pada soal no. 3 memiliki ukuran yang sama. Ketika dilakukan wawancara AD tidak dapat memberikan alasan yang tepat bahwa tidak ada segitiga yang paling luas hanya dilogika saja, dapat dilihat dari cuplikan wawancara 7 sebagai berikut.

P : Kenapa kog ke 3 segitiga itu bisa sama luasnya, kan itu beda-beda segitiganya?

AD : Ya emang sama saya logika aja

P : Coba jelaskan bagaimana logikanya?

AD : Ehmm itu mas, kan alasnya sama, (terdiam) terus panjang sisiya sama kan, sama ukuranya menurut saya

Subjek AD telah mencapai tahap 1 (analisis), dapat menentukan jenis segitiga, dan dapat menyebutkan nama-nama segitiga. Hal tersebut dapat dilihat pada cuplikan wawancara 8 sebagaiberikut.

$\begin{array}{ll}\mathbf{P} & : \text { Soal no.3 itu disuruh mencari apa? } \\ \mathrm{AD} & : \text { Segitiga mana yang paling luas } \\ \mathbf{P} & : \text { Ada berapa segitiga pada soal no.3? } \\ \mathrm{AD} & : \text { : Ehm ee (sambil berpikir) 7, oh tiga deh mas } \\ \mathbf{P} & : \text { Segitiga apa saja? } \\ \mathrm{AD} & : \text { Segitiga ABE, segitiga ACE, sama segitiga ADE } \\ \mathbf{P} & : \text { Kalau segitiga ACE itu jenis segitiga apa? } \\ \mathrm{AD} & \text { : Segitiga sama kaki }\end{array}$

3. Profil Kemampuan Pemecahan Masalah Subjek dengan Hasil Belajar Matematika Rendah (MA)

Hasil analisis data penelitian menunjukan bahwa siswa dengan hasil belajar matematika rendah pada soal no. 1 tidak mencapai tahap 0 (visualisasi), karena subjek MA tidak dapat menentukan jenis segitiga yang diminta pada soal (lihat gambar 8).

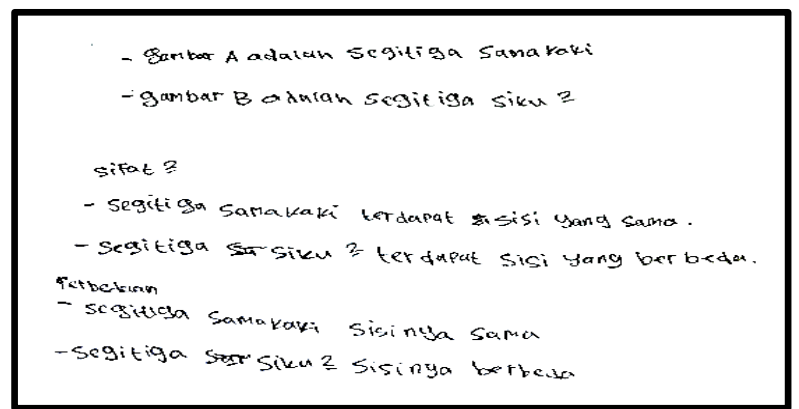

Gambar 8. Jawaban subjek MA soal 1 
Jawaban tertulis subjek MA terlihat bahwa segitiga sama sisi adalah segitiga sama kaki dan segitiga sama kaki adalah segitiga sikusiku. Kurangnya pengetahuan subjek AD tentang konsep segitiga mengakibatkan subjek AD tidak mampu menetukan jenis-jenis segitiga, menentukan sifat-sifat dan ciri-ciri segitiga, serta membedakan segitiga pada soal. Subjek MA pada soal no. 1 belum mencapai tahap 0 (visualisasi)

Hasil analisis data penelitian menunjukan bahwa siswa dengan hasil belajar matematika rendah pada soal no. 2 tidak mencapai tahap 0 (visualisasi), kerena subjek MA tidak dapat menggambar segitiga siku-siku, tidak dapat menghitung keliling segitiga dengan tepat, tidak menggunakan rumus Pythagoras, serta salah konsep penjumlahan aljabar. Hal tersebut dapat dilihat pada gambar 9 .

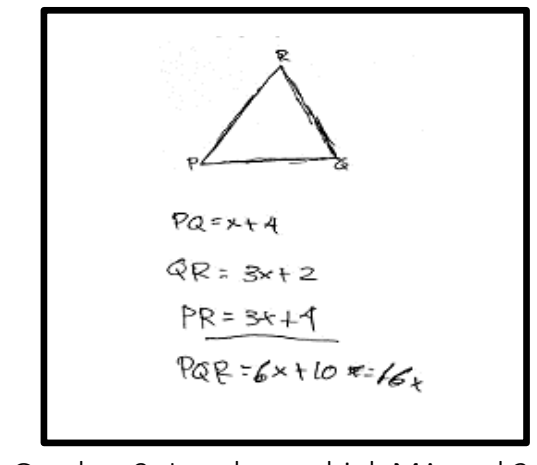

Gambar 9. Jawaban subjek MA soal 2.

Jawaban tertulis terlihat bahwa subjek MA tidak dapat menggambar segitiga siku-siku dengan benar. Hal tersebut sejalan dengan hasil jawaban pada soal no. 1 dimana pengetahuan subjek MA tentang konsep segitiga masih kurang. Cara subjek MA menghitung keliling segitiga adalah dengan menjumlahkan panjang sisi yang telah diketahui dalam bentuk aljabar dengan hasil jawaban 16x. Terlihat subjek MA belum menguasai konsep penjumlahan aljabar hal ini terbukti dari cuplikan wawancara 9 sebagai berikut.
P

MA

Ok langsung saja ya, kemarin cara kamu memperoleh jawaban no 2 ini bagaimana?

MA : Ehmm, itu mas kemarin saya menjumlah panjang $\mathrm{PQ}$ itu kan $x+4$ jadinya $4 x$, terus panjang QR kan $3 x+2$ jadinya $5 x$, yang PR $3 x+4$ kan hasilnya $7 x$ kemudian tak jumlah semua mas jadinya kan $16 x$

Hasil analisis data penelitian menunjukan bahwa siswa dengan matematika rendah pada soal no. 3 mencapai tahap 0 (visualisasi), karena subjek MA menemukan segitiga yang paling luas dari soal no. 3 yaitu segitiga ACE. Dapat dilihat pada gambar 10.

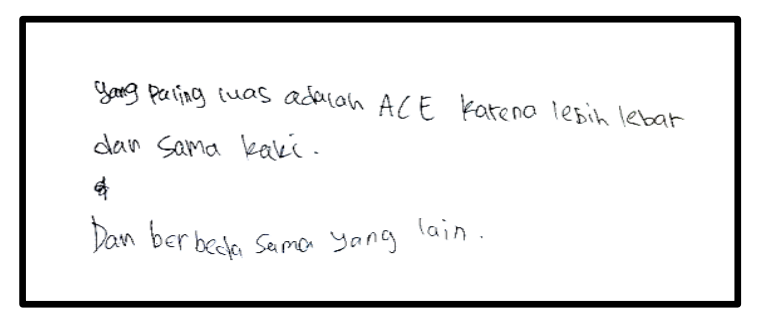

Gambar 10. Jawaban subjek MA soal 3.

Jawaban tertulis MA menunjukan bahwa subjek MA menemukan bahwa segita ACE adalah segitiga yang paling luas dengan alasan segitiga ACE adalah segitiga sama kaki serta lebih besar daripada segitiga yang lain, alasan tersebut dirasa kurang tepat. Kurangnya pengetahuan MA tentang konsep luas segitiga mengakibatkan MA mengalami kesalahan dalam menjawab soal no. 3 luas segitiga pada soal.

Jawaban tertulis MA pada soal no. 3 tidak menunjukkan bahwa MA mampu mencapai tahap 0 (visualisasi) namun saat dilakukan wawancara MA mampu mengidentifikasi segitiga yang terdapat pada soal no. 3, hal tersebut dapat dilihat pada cuplikan wawancara 10 sebagai berikut.

$\begin{array}{ll}\text { P } & \text { : Menurut kamu ada berapa segitiga pada soal ? } \\ \text { MA } & \text { : Eee ada lima, (sambil menghitung), ehh ada } 3 \\ \text { P } & \text { : Segitiga apa saja } \\ \text { MA } & \text { : Segitiga ABE, segitiga ACE, sama segitiga ADE } \\ \text { P } & \text { : Segitiga ACE itu jenis segitiga apa ? } \\ \text { MA } & \text { : Segitiga ACE itu segitiga sama kaki } \\ \text { P } & \text { : Kalau segitiga ADE ? } \\ \text { MA } & \text { : Segitiga siku-siku }\end{array}$


P : Tunjukkan sudut siku-sikunya ?

MA : Ini sudut E (menunjuk sudut E)

Bedasarkan analisis jawaban tertulis dan wawancara subjek MA pada soal no. 3 mencapai tahap 0 (visualisasi).

\section{B. Pembahasan}

Pembahasan dari analisis ketiga subjek Hasil analisis jawaban terulis dan wawancara dari ketiga soal yang diberikan, subjek dengan hasil belajar matematika tinggi (NN) berada pada Tahap 0 (visualisasi). Subjek dapat melakukan pengamatan, menggambar, dan membuat model dalam menentukan sifat-sifat suatu bangun, dan subjek melihat hubungan antar beberapa bangun geometri akan tetapi saat menggambar segitiga siku-siku subjek belum bisa menggambar segitiga dengan tepat. Sholihah \& Afriansyah (2017) menemukan bahwa subjek dengan kemampuan matematika tinggi hanya sampai pada Tahap 0 (visualisasi). Subjek cenderung mengenal bentuk-bentuk geometri dari karakteristik visual yang tampak, subjek telah memahami dan menentukan sifat-sifat serta ciri-ciri segitiga yang ditunjukkan pada soal, akan tetapi subjek NN tidak dapat menentukan jenis segitiga. Hal ini sejalan dengan penelitian Muhassanah, dkk (2014) bahwa siswa membuat bentuk geometri berdasarkan penampilan fisik secara keseluruhan.

Berdasarkan hasil analisis jawaban tertulis dan wawancara secara keseluruhan, subjek dengan hasil belajar matematika sedang (AD) berada pada Tahap 1 (analisis), subjek telah mengenal bentuk-bentuk geometri dari karakteristik visual yang tampak, dan subjek memahami dan menentukan sifat geometri yang ditunjukkan dalam mengelompokkannya.
Subjek sudah bisa menentukan jenis segitiga yang terdapat pada soal dengan menyebutkan sifat-sifat segitiga dari dua segitiga yang berbeda. Subjek juga telah melakukan pengamatan, menggambar, dan membuat model dalam menentukan sifat-sifat suatu bangun, dan subjek melihat hubungan antar beberapa bangun geometri Hasil penelitian ini sejalan dengan penelitian yang dilakukan oleh Muhassanah, dkk (2014) yaitu pada siswa Tahap 1 (analisis) dapat menyebutkan sifatsifat dalam gambar dan mampu mengkontruksi gambar sesuai dengan sifatsifat informasi yang diberikan. Nurani, dkk (2016) menemukan bahwa subjek dengan matematika sedang mampu mencapai tahap 1 (analisis).

Berdasarkan hasil analisis dan wawancara dari ketiga soal yang diberikan, subjek dengan matematika rendah (MA) berada pada Tahap 0 (visualisasi). Subjek cenderung mengenal bentuk-bentuk geometri dari karakteristik visual yang tampak, dan subjek memahami dan menentukan sifat geometri yang ditunjukkan dalam mengelompokkannya akan tetapi subjek masih belum bisa menentukan jenis segitiga yang terdapat pada soal, hal ini disebabkan karena kurangnya pengetahuan subjek pada konsep segitiga. Sejalan dengan penelitian Budiarti dan Mahendra (2020) yang menyatakan bahwa subjek pada Tahap visualisasi tidak dapat membuat model matematika. Sedangkan Sholihah \& Afriansyah (2017) menemukan bahwa subjek dengan hasil belajar matematika rendah hanya sampai Tahap visualisasi.

\section{Penutup}

Kesimpulan dari penelitian ini adalah kemampuan pemecahan masalah yang dimiliki 
setiap siswa berbeda-beda hal ini disebabkan karena tingkat berpikir siswa berbeda-beda. Sehingga guru matematika diharapkan dapat menggunakan metode yang tepat dalam mengajar dan menggunakan contoh soal konseptual agar materi pembelajaran dapat tersampaikan dengan baik dan setiap siswa dapat memahami apa yang telah disampaikan oleh guru. Penelitian ini dapat dilanjutkan yang difokuskan pada kemampuan pemecahan masalah matematika siswa berdasarkan teori Van Hiele.

\section{Daftar PUStaka}

Afriansyah, E. A. (2015). Qualitative Became Easier with ATLAS. ti. In International Seminar on Mathematics, Science, and Computer Science Education MSCEIS.

Afriansyah, E. A. (2016). The Use of Realistic Approach to Enhance Students' Mathematical Problem Solving Skills. In International Conference on Elementary and Teacher Education ICETE.

Albab, I. U., Saputro, B. A., \& Nursyahidah, F. (2017). Peningkatan kemampuan pemecahan masalah matematis mahasiswa melalui collaborative analysis of sample student responses. Mosharafa: Jurnal Pendidikan Matematika, 6(1), 3544.

Asih, N., \& Ramdhani, S. (2019). Peningkatan Kemampuan Pemecahan Masalah Matematis dan Kemandirian Belajar Siswa Menggunakan Model Pembelajaran Means End Analysis. Mosharafa: Jurnal Pendidikan Matematika, 8(3), 435-446. https://doi.org/https://doi.org/10.31980/ mosharafa.v8i3.534

Asmara, R., \& Afriansyah, E. A. (2018). Perbedaan Peningkatan Kemampuan Komunikasi Matematis Siswa antara
Model Eliciting Activities dan Discovery Learning. Suska Journal of Mathematics Education, 4(2), 78-87.

Budiarti dan Mahendra (2020). Analisis Pemecahan Masalah Geometri Berdasarkan Tingkat Berpikir Teori Van Hiele Dan Gender. Pi: Mathematics Education Journal, 3(1), 28-37

Croft, T., Kouvela, E., \& Martinez, P. M. (2018). This is what you need to be learning: an analysis of messages received by first-year mathematics students during their transition to university. Math Ed Res J, 30(1), 165-183. https://doi.org/10.1007/s13394-0170226- 2.

Ekayanti, A. (2017). Diagnosis Kesalahan Mahasiswa Dalam Proses Pembuktian Berdasarkan Newmann Error Analysis. Mosharafa: Jurnal Pendidikan Matematika, 6(1), 105-116.

Faelasofi, dkk. (2015). Metode Pembelajaran Mind Mapping untuk Meningkatkan Kemampuan Komunikasi Matematik Siswa Dalam Pemecahan Masalah Matematika. Jurnal e-DuMath, 1. 122136.

Kurniawati, V., \& Rizkianto, I. (2018). Pengembangan Perangkat Pembelajaran Matematika Berbasis Guided Inquiry dan Learning Trajectory Berorientasi pada Kemampuan Pemecahan Masalah. Mosharafa: Jurnal Pendidikan Matematika, 7(3), 369-380.

Latifah, D., \& Madio, S. S. (2014). Meningkatkan Kemampuan Pemecahan Masalah Matematis Siswa Melalui Model Pembelajaran Missouri Mathematics Project (MMP). Mosharafa: Jurnal Pendidikan Matematika, 3(3), 159-168. 
Lisnani, L., \& Asmaruddin, S. N. (2018). Desain

Buku Ajar Matematika Bilingual Materi Bangun Datar Menggunakan Pendekatan PMRI Berkonteks Kebudayaan Lokal. Mosharafa: Jurnal Pendidikan Matematika, 7(3), 345-356.

Lisnani, L. (2019). Pemahaman Konsep Awal Calon Guru Sekolah Dasar Tentang Pecahan. Mosharafa: Jurnal Pendidikan Matematika, 8(1), 61-70.

Muhammad, G. M., Septian, A., \& Sofa, M. I. (2018). Penggunaan Model Pembelajaran Creative Problem Solving untuk Meningkatkan Kemampuan Pemecahan Masalah Matematis Siswa. Mosharafa: Jurnal Pendidikan Matematika, 7(3), 315326.

Muhassanah, N. (2014). Analisis Keterampilan Geometri Siswa dalam Memecahkan Masalah Geometri Berdasarkan Tingkat Berpikir Van Hiele. Journal Elektronik Pembelajaran Matematika, 2(1).

Musa, L. A. D. (2018). Level Berpikir Geometri Menurut Teori Van Hiele Berdasarkan Kemampuan Geometri dan Perbedaan Gender Siswa Kelas VII SMPN 8 Pare-Pare. Al-Khwarizmi: Jurnal Pendidikan Matematika Dan IImu Pengetahuan Alam, 4(2), 103-116. https://doi.org/10.24256/jpmipa.v4i2.255 Muslim, S. R., \& Prabawati, M. N. (2020). Studi Etnomatematika terhadap Para Pengrajin Payung Geulis Tasikmalaya Jawa Barat. Mosharafa: Jurnal Pendidikan Matematika, 9(1), 59-70.

Mustakim \& Budiarto, M. T. (2017). Identifikasi Kreativitas Siswa SMP dalam Menyelesaikan Masalah Luas Segiempat.
Jurnal Ilmiah Pendidikan Matematika, 2(6).

Nadz, T. F., \& Haq, C. N. (2013). Perbandingan Peningkatan Kemampuan Penalaran Matematis Siswa yang Memperoleh Pembelajaran melalui Metode Problem Based Instruction (Pbi) dengan Metode Konvensional. Mosharafa: Jurnal

Pendidikan Matematika, 2(3), 191-202.

Nurani, I. F., Irawan, E. B., \& Sa'dijah, C. (2016). Level Berpikir Geometri Van Hiele Berdasarkan Gender pada Siswa Kelas VII SMP Islam Hasanuddin Dau Malang. Jurnal Pendidikan, 1(5), 978-983.

Rahmiati, R., Musdi, E., \& Fauzi, A. (2017). Pengembangan Perangkat Pembelajaran Matematika Berbasis Discovery Learning untuk Meningkatkan Kemampuan Pemecahan Masalah Siswa Kelas VIII SMP. Mosharafa: Jurnal Pendidikan Matematika, 6(2), 267-272.

Rinaldi, E., \& Afriansyah, E. A. (2019). Perbandingan Kemampuan Pemecahan Masalah Matematis Siswa antara Problem Centered Learning dan Problem Based Learning. NUMERICAL: Jurnal Matematika dan Pendidikan Matematika, 9-18.

Rismen, S., Mardiyah, A., \& Puspita, E. M. (2020). Analisis Kemampuan Penalaran dan Komunikasi Matematis Siswa. Mosharafa: Jurnal Pendidikan Matematika, 9(2), 263-274.

Shadiq, F. (2009). Kemahiran matematika. Yogyakarta: Depdiknas.

Sholihah, S. Z., \& Afriansyah, E. A. (2018). Analisis Kesulitan Siswa dalam Proses Pemecahan Masalah Geometri Berdasarkan Tahapan Berpikir Van Hiele. Mosharafa: Jurnal Pendidikan Matematika, 6(2), 287-298. 
https://doi.org/10.31980/mosharafa.v6i2. 317

Siregar, N. (2016). Meninjau Kemampuan Penalaran Matematis Siswa SMP melalui Wawancara Berbasis Tugas Geometri. Mosharafa: Jurnal Pendidikan Matematika, 5(2), 128-137.

Sopian, Y. A., \& Afriansyah, E. A. (2017). Kemampuan Proses Pemecahan Masalah Matematis Siswa melalui Model Pembelajaran Creative Problem Solving dan Resource Based Learning. Jurnal Elemen, 3(1), 97-107.

Studi Pendidikan Matematika STKIP Muhammadiyah Pringsewu Lampung, P., Faelasofi, R., Arnidha, Y., Istiani, A., Matematika, P., \& Muhammadiyah Pringsewu, S. (2015). Metode Pembelajaran Mind Mapping untuk Meningkatkan Kemampuan Komunikasi Matematik Siswa Dalam Pemecahan Masalah Matematika. JURNAL E-DuMath, 1(2), 122-136.

https://doi.org/10.26638/JE.116.2064

Suryani, M., Jufri, L. H., \& Putri, T. A. (2020). Analisis Kemampuan Pemecahan Masalah Siswa Berdasarkan Kemampuan Awal Matematika. Mosharafa: Jurnal

Pendidikan Matematika, 9(1), 119-130.

Tristiyanti, T., \& Afriansyah, E. A. (2017). Kemampuan Pemecahan Masalah Matematis Siswa Melalui Model Pembelajaran Kooperatif Tipe Diskursus Multi Representasi Dan Reciprocal Learning. Jurnal Silogisme: Kajian IImu Matematika Dan Pembelajarannya, 1(2), 4-14.

Yustianingsih, R., Syarifuddin, H., \& Yerizon, Y. (2017). Pengembangan Perangkat Pembelajaran Matematika Berbasis Problem Based Learning (PBL) untuk
Meningkatkan Kemampuan Pemecahan Masalah Peserta Didik Kelas VIII. JNPM (Jurnal Nasional Pendidikan Matematika), 1(2), 258.

https://doi.org/10.33603/jnpm.v1i2.563

Van de Walle. (2006). Matematika Sekolah Dasar dan Menengah Jilid 2. Edisi keenam. Diterjemahkan oleh: Suyono. Jakarta: Erlangga.

Wahyuni, R. (2016). Upaya Peningkatan Kemampuan Pemecahan Masalah Matematis Siswa dengan Pendidikan Matematika Realistik Indonesia. Mosharafa: Jurnal Pendidikan Matematika, 5(2), 85-92.

Wardani, S. (2012). Pembelajaran Inkuiri Model Silver untuk Mengembangkan Kemampuan Pemecahan Masalah dan Disposisi Matematik Siswa Sekolah Menengah Atas. Mosharafa: Jurnal Pendidikan Matematika, 1(1), 9-16.

\section{Riwayat Hidup PenUlis}

\section{Viyang Firnanda}

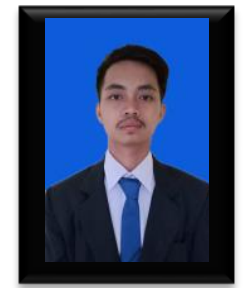

Lahir di Pati, 15 Januari 1998. Mahasiswa Prorgram Studi S1 FKIP Progdi Pendidikan Matematika Universitas Kristen Satya Wacana, Salatiga.

\section{Fika Widya Pratama, S.Si., M.Pd}

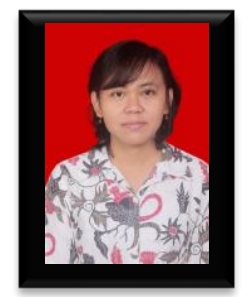

Staf pengajar di FKIP Progdi Pendidikan Matematika Universitas Kristen Satya Wacana, Salatiga. 